\title{
0427. Respiratory effects of noisy ventilation depend on the etiology of acute respiratory distress syndrome
}

\author{
L Moraes $^{1 *}$, C Samary ${ }^{1}$, RS Santos ${ }^{1}$, DS Ornellas ${ }^{1}$, CL Santos ${ }^{1}$, NS Felix ${ }^{1}$, R Huhle ${ }^{2}$, P Pelosi ${ }^{3}$, M Gama de Abreu², \\ PL Silva', PRM Rocco ${ }^{1}$
}

From ESICM LIVES 2014

Barcelona, Spain. 27 September - 1 October 2014

\section{Introduction}

Healthy biological systems are characterized by intrinsic variability of their function, including the respiratory system. However, during pathological conditions, as observed in acute respiratory distress syndrome (ARDS), this biological variability can be lost, and the institution of variable ventilation (noisy, $\mathrm{VV}$ ) may lead to morphofunctional improvement compared with conventional ventilation $(\mathrm{CV})$. However, it is not known if this beneficial effect is dependent on the etiology of ARDS. In pulmonary ARDS (ARDSp) there is a predominance of lung tissue consolidation, whereas extrapulmonary ARDS (ARDSexp) is associated with alveolar collapse.

\section{Objectives}

The aim of the present study was to compare variable ventilation with conventionalventilation in experimental ARDSp and ARDSexp.

\section{Methods}

In twenty-four Wistar rats (365 $\pm 55 \mathrm{~g}), \mathrm{ARDSp}$ and ARDSexp were induced by lipopolysaccharide (LPS) administered either intratracheally $(200 \mu \mathrm{g})$ or intraperitoneally $(1,000 \mu \mathrm{g})$, respectively. After $24 \mathrm{~h}$, animals were mechanically ventilated with: tidal volume $\left(\mathrm{V}_{\mathrm{T}}\right)=6 \mathrm{ml} / \mathrm{kg}$, respiratory rate $(R R)=80 \mathrm{bpm}$, positive end-expiratory pressure $(\mathrm{PEEP})=0 \mathrm{cmH}_{2} \mathrm{O}$, and fraction of inspired oxygen $\left(\mathrm{FiO}_{2}\right)=0.4$. Baseline data were collected to evaluate if ARDSp and ARDSexp animals presented similar degree of lung damage. Rats were then randomly assigned to be mechanically ventilated with VV or CV. VV was applied

Laboratory of Pulmonary Investigation, Carlos Chagas Filho Biophysics

Institute, Federal University of Rio de Janeiro, Rio de Janeiro, Brazil

Full list of author information is available at the end of the article on a breath-to-breath basis as sequence of randomly generated $V_{T}$ values $\left(n=600\right.$; mean $\left.V_{T}=6 \mathrm{ml} / \mathrm{kg}\right)$, with $30 \%$ of coefficient of variation. After randomization, all animals were ventilatedfor $1 \mathrm{~h}$, and lungs were removed for histology.

\section{Results}

Variable ventilation led to decreasedrespiratory system and transpulmonary pressures in ARDSp $(\mathrm{p}<0.05)$, but not in ARDSexp. Furthermore, in ARDSp, the increment of lung resistance along $1 \mathrm{~h}$ was minimized in VV compared to $\mathrm{CV}$ (7\% vs. $31 \%$, respectively). Oxygenation increased in $\mathrm{VV}$ and $\mathrm{CV}$ regardless of ARDS etiology. Nevertheless, animals that underwent VV presented a higher percentage of increase in arterial oxygen partial pressure compared to those that underwent CV (ARDSp, $50 \%$ vs. 26\%; ARDSexp, $100 \%$ vs. $53 \%$, respectively). In ARDSp, but not in ARDSexp, there was a decrease in collapsed areas in VV compared to CV $(\mathrm{p}<0.001)$.

\section{Conclusions}

In the present model of ARDSp and ARDSexp, oxygenation improved independent of ARDS etiology, however, respiratory system and transpulmonary pressures as well as collapsed areas reduced only in ARDSp. Therefore, the morphofunctional improvement in animals ventilated with VV is dependent on ARDS etiology, and this achievement could be related to better recruitment.

Grant acknowledgment

PRONEX-FAPERJ, FAPERJ, CNPq, CAPES. 


\section{Authors' details}

'Laboratory of Pulmonary Investigation, Carlos Chagas Filho Biophysics

Institute, Federal University of Rio de Janeiro, Rio de Janeiro, Brazil.

${ }^{2}$ Department of Anesthesiology and Intensive Care Therapy, University

Hospital Carl Gustav Carus, Dresden, Germany. ${ }^{3}$ RCCS AOU San Martino-IST,

Department of Surgical Sciences and Integrated Diagnostics, University of

Genoa, Genoa, Italy.

Published: 26 September 2014

\section{Reference}

1. Gama de Abreu M, Spieth P, Pelosi P, et al: Noisy pressure support ventilation: a pilot study on a new assisted ventilation mode in experimental lung injury. Crit Care Med 2008, 36:818-827.

doi:10.1186/2197-425X-2-S1-P25

Cite this article as: Moraes et al:: 0427. Respiratory effects of noisy ventilation depend on the etiology of acute respiratory distress syndrome. Intensive Care Medicine Experimental 2014 2(Suppl 1):P25.

\section{Submit your manuscript to a SpringerOpen ${ }^{\mathcal{O}}$ journal and benefit from:}

- Convenient online submission

- Rigorous peer review

- Immediate publication on acceptance

- Open access: articles freely available online

- High visibility within the field

- Retaining the copyright to your article

Submit your next manuscript at $\gg$ springeropen.com 